\title{
Activation of GPER Induces Differentiation and Inhibition of Coronary Artery Smooth Muscle Cell Proliferation
}

\author{
Fen $\mathrm{Li}^{1,4}$, Xuan $\mathrm{Yu}^{1}$, Claudia K. Szynkarski ${ }^{1}$, Cong Meng ${ }^{2}$, Beiyan Zhou ${ }^{2}$, Rola Barhoumi ${ }^{3}$, \\ Richard E. White ${ }^{5}$, Cristine L. Heaps ${ }^{1}$, John N. Stallone', Guichun Han ${ }^{1 *}$
}

1 Women's Health Division, Michael E. DeBakey Institute, Texas A\&M University, College Station, Texas, United States of America, 2 Department of Physiology and Pharmacology, Texas A\&M University, College Station, Texas, United States of America, 3 Department of Veterinary Integrative Biosciences, College of Veterinary Medicine and Biomedical Sciences, Texas A\&M University, College Station, Texas, United States of America, 4 College of Life Science, Henan Normal University, Xinxiang, Henan Province, P. R. China, 5 Department of Basic Sciences, Philadelphia College of Osteopathic Medicine-Georgia Campus, Suwanee, Georgia, United States of America

\begin{abstract}
Background: Vascular pathology and dysfunction are direct life-threatening outcomes resulting from atherosclerosis or vascular injury, which are primarily attributed to contractile smooth muscle cells (SMCs) dedifferentiation and proliferation by re-entering cell cycle. Increasing evidence suggests potent protective effects of G-protein coupled estrogen receptor 1 (GPER) activation against cardiovascular diseases. However, the mechanism underlying GPER function remains poorly understood, especially if it plays a potential role in modulating coronary artery smooth muscle cells (CASMCs).

Methodology/Principal Findings: The objective of our study was to understand the functional role of GPER in CASMC proliferation and differentiation in coronary arteries using from humans and swine models. We found that the GPER agonist, G-1, inhibited both human and porcine CASMC proliferation in a concentration- $\left(10^{-8}\right.$ to $\left.10^{-5} \mathrm{M}\right)$ and time-dependent manner. Flow cytometry revealed that treatment with G-1 significantly decreased the proportion of S-phase and G2/M cells in the growing cell population, suggesting that G-1 inhibits cell proliferation by slowing progression of the cell cycle. Further, G-1-induced cell cycle retardation was associated with decreased expression of cyclin B, up-regulation of cyclin D1, and concomitant induction of p21, and partially mediated by suppressed ERK1/2 and Akt pathways. In addition, G-1 induces SMC differentiation evidenced by increased $\alpha$-smooth muscle actin ( $\alpha$-actin) and smooth muscle protein $22 \alpha$ (SM22 $\alpha$ ) protein expressions and inhibits CASMC migration induced by growth medium.

Conclusion: GPER activation inhibits CASMC proliferation by suppressing cell cycle progression via inhibition of ERK1/2 and Akt phosphorylation. GPER may constitute a novel mechanism to suppress intimal migration and/or synthetic phenotype of VSMC.
\end{abstract}

Citation: Li F, Yu X, Szynkarski CK, Meng C, Zhou B, et al. (2013) Activation of GPER Induces Differentiation and Inhibition of Coronary Artery Smooth Muscle Cell Proliferation. PLoS ONE 8(6): e64771. doi:10.1371/journal.pone.0064771

Editor: Rudolf Kirchmair, Medical University Innsbruck, Austria

Received December 10, 2012; Accepted April 18, 2013; Published June 19, 2013

Copyright: (C) $2013 \mathrm{Li}$ et al. This is an open-access article distributed under the terms of the Creative Commons Attribution License, which permits unrestricted use, distribution, and reproduction in any medium, provided the original author and source are credited.

Funding: This work is supported by Beginning Grant-In-Aid from American Heart Association [11BGIA7370061 to G.H.]. Confocal microscopy was performed in the Texas A\&M University College of Veterinary Medicine \& Biomedical Sciences Image Analysis Laboratory, supported by NIH-NCRR (1S10RR22532-01), and NIH grants P30-ES09106, P42-ES04917, T32 ES07273 and R01 ES002710. The funders had no role in study design, data collection and analysis, decision to publish, or preparation of the manuscript.

Competing Interests: The authors have declared that no competing interests exist.

*E-mail: ghan@crm.tamu.edu

\section{Introduction}

Vascular smooth muscle cells (VSMCs) constitute the major structural component of the vasculature, and are crucial to maintaining vessel tone, blood pressure, and blood flow. Adult VSMCs retain remarkable plasticity, and can undergo profound and reversible phenotypic changes in response to local environmental stimuli. Normally, VSMCs exhibit a "contractile" or differentiated phenotype characterized by the expression of specific contractile markers (e.g., myosin heavy chain and $\alpha$-actin) [1]; however, injured VSMCs dedifferentiate and re-enter the cell cycle with an increased rate of proliferation and migration. Further, expression of myosin heavy chain and $\alpha$-actin is decreased in the proliferative stage. This dedifferentiated phenotype plays a major pathophysiologic role in the development of atherosclerosis, restenosis after angioplasty, and hypertension [2].
Estrogen (17 $\beta$-estradiol or E2) lowers the risk of cardiovascular disease in women [3], and inhibits VSMC proliferation following injury [4-10]. Interestingly, the anti-proliferative action of E2 persists in $\mathrm{ER} \alpha$-deficient, $\mathrm{ER} \beta$-deficient, or $\mathrm{ER} \alpha / \mathrm{ER} \beta$-doubleknockout mice [11-13]. Thus, the anti-proliferative effect of E2 may involve a novel ER protein. The recently discovered $G$ protein-coupled estrogen receptor 1 (GPER) is a seven transmembrane-domain $\mathrm{G}$ protein receptor structurally unrelated to $\mathrm{ER} \alpha$ or $\mathrm{ER} \beta$, binds E2 with high affinity, and mediates estrogenic signaling [14,15]. The selective GPER agonist, G-1, lowers blood pressure in either normotensive [16] or mRen2. Lewis hypertensive rats [17], whereas GPER gene knockout female mice exhibit increased blood pressure-presumably due to increased total vascular resistance associated with arterial wall remodeling [18]. In addition, G-1 improves functional recovery from myocardial ischemiareperfusion by reducing post-ischemic contractile dysfunction and 
infarct size [19]. Thus, GPER is a potential mediator of estrogen action on coronary arteries, but whether GPER plays a role in coronary artery smooth muscle cell (CASMC) proliferation is unknown.

In the present study, we demonstrate that G-1 inhibits seruminduced VSM proliferation in both human and porcine coronary arteries, and have characterized downstream signaling events. We have also investigated the effect of G-1 on the re-differentiation and migration of CASMC. Our data provide new insight into the mechanisms of estrogen receptor signaling in VSMC, and reveal GPER to be a target for the development of therapeutic strategies in vascular diseases.

\section{Materials and Methods}

\section{Reagents}

Recombinant human PDGF-BB was purchased from Sigma Company. G-1 was purchased from Cayman Chemical Company and dissolved in DMSO, and the concentration of DMSO was less than $0.05 \%$ in the control and drug-containing medium.

\section{Isolation of porcine CASMCs and culture of porcine and human CASMCs}

Porcine hearts were obtained from and permitted by local abattoirs, K\&C meat processing. Coronary arteries were dissected, and CASMCs were enzymatically dispersed [20]. Primary cultured porcine CASMCs (PCASMC) and human CASMCs (HCASMC, Cascade Biologics, C-017-5C) were maintained in Medium 231 with Smooth Muscle growth Supplement (SMGS) (GIBCO USA), $100 \mu \mathrm{g} / \mathrm{ml}$ penicillin and $100 \mu \mathrm{g} / \mathrm{ml}$ streptomycin. Cell cultures were kept at $37^{\circ} \mathrm{C}$ and under $5 \% \quad \mathrm{CO}_{2}$ in a humidified incubator. CASMCs were cultured to $80 \%$ confluence, and we employed passage 2-3 for porcine CASMCs or passage 68 for human CASMCs.

\section{Cell proliferation assay}

CASMCs were seeded onto 6 -well plates $\left(1 \times 10^{5}\right.$ cells per well $)$ for $24 \mathrm{~h}$ for attaching and then serum-deprived in phenol red free MEM $\alpha$ medium (GIBCO USA) for $72 \mathrm{~h}$ before treatment with G-1 or PDGF-BB $(10 \mathrm{ng} / \mathrm{ml})$ with $10 \%$ Charcoal Stripped FBS (FCS) (GIBCO USA). Cell proliferation was determined by daily counting the number of cells in triplicate.

\section{Cell cycle progression analysis}

Cell cycle progression assay was performed by RNase staining followed by FACS (fluorescence-activated cell sorter) analysis. Distribution of CASMCs cells in the cell cycle was determined by flow cytometry of propidium iodide-stained nuclei as described by Odenlund et al [21]. Briefly, flow-cytometric DNA analysis was performed in a FACS Calibur flow cytometer equipped with data acquisition capability.

\section{Cellular migration analysis}

Analysis of cellular motility/migration was carried out using Culture-Inserts ready to use in a $\mu$-Dish $35 \mathrm{~mm}$ (ibiTreat, item \#: 81176 , IBIDI), which allows performing high resolution microscopy in a $35 \mathrm{~mm}$ Petri-dish with $12 \mathrm{~mm}$ walls. PCASMCs were seeded in Medium 231 with SMGS (GIBCO USA), $100 \mu \mathrm{g} / \mathrm{ml}$ penicillin and $100 \mu \mathrm{g} / \mathrm{ml}$ streptomycin. When cells reached $100 \%$ confluence, the inserts were taken out and a $500 \mu \mathrm{M}$ gap was left in each dish. Cells were then grown in fresh control media, or media+drug treatment (e.g., G-1 or G-1+G-15), and cells were allowed to migrate for $48 \mathrm{~h}$. Images were collected with a Stallion
Digital Imaging workstation (Carl Zeiss) equipped with a HQ CoolSnap camera (Photometrics) and a $5 \times$ objective. Five images per treatment were collected before and after $48 \mathrm{~h}$ following removal of the inserts. Within a specific image five different distances were measured from the edge marked by a dotted black line. Data collected represent the mean distance traveled from the edge.

\section{Western blot analysis}

After human CASMCs $\left(1 \times 10^{5}\right)$ were cultured in a $6 \mathrm{~cm}$ diameter dish for $48 \mathrm{~h}$, they were starved in serum-free medium for another $48 \mathrm{~h}$. Cells were then treated with G-1 $(1 \mu \mathrm{M}$, from Calbiochem) and PDGF-BB (10 ng/ml, from Sigma-Aldrich Corporation). For cell cycle protein extracts, cells were starved in serum-free medium for $72 \mathrm{~h}$ before G-1 treatment. Harvested cells were disrupted, and the protein concentration was determined using BCA assay according to the manufacturer's instructions. Proteins were detected with the following antibodies: anti-cyclinB1 (sc-7393 Santa Cruz, 1:200), anti-cyclin D1 (sc20044 Santa Cruz, 1:200), anti-p21 (sc-6246 Santa Cruz, 1:100), anti-pERK1/2 (No. 9101s Cell Signaling, 1:1000), anti-pAKT (No. 4060s Cell Signaling, 1:1000), anti- $\alpha$-actin (ab5694 Abcam, 1:4000), anti-SM22 $\alpha$ (ab14106 Abcam, 1:5000), anti- $\beta$-actin (ab8227 Abcam, 1:1000), or anti-GAPDH (sc-25778 Santa Cruz, 1:1000). After chemiluminescence detection (EMD Millipore, Billerica, MA, USA), Image J software was used for data analysis. The experiments were replicated three times.

\section{Immunocytochemistry}

Human and porcine CASMCs seeded on $12 \mathrm{~mm}$ glass coverslips placed in 6 well plates were serum-deprived for $48 \mathrm{~h}$, and then treated for 1-2 days with vehicle, SMDS, or G-1 in phenol red free MEM $\alpha$ medium. Cells were then fixed in $10 \%$ buffered formalin for $10 \mathrm{~min}$, washed twice with PBS, and permeabilized in $0.2 \%$ Triton X-100 and PBS for $10 \mathrm{~min}$. CASMCs were washed twice with PBS, and incubated with $4 \%$ BSA-PBS for $1 \mathrm{~h}$, then with anti- $\alpha$-actin antibody overnight at $4^{\circ} \mathrm{C}$ and incubated with FITC-conjugated anti-rabbit IgG antibody (PAl-29388 Thermo Scientific Pierce) for $1 \mathrm{~h}$ at room temperature in darkness. After three washes with PBS, the coverslips were mounted for imaging.

\section{Transfection of siRNA}

Human CASMCs were transfected in 6- or 12-well dishes at 30-60\% confluence with $75 \mathrm{nM}$ siRNA using Lipofectamine 2000 (Invitrogen) according to the manufacturer's instructions. The cells were studied $48 \mathrm{~h}$ after transfection. Transfected cells were then treated with $\mathrm{G}-1(10 \mathrm{nM}$ or $1 \mu \mathrm{M})$ for $48 \mathrm{~h}$. For determination the effect of silencing GPER on decreased PCNA expression and cell morphology change caused by G-1 treatment, immunocytochemistry was carried out as described above. For determination of silencing efficiency, Western blotting was performed and membrane was probed with GPER antibody.

\section{Statistics analysis}

Data are presented as means \pm standard deviation $(\mathrm{SD})$ and analyzed with Prism program (GraphPad Software Inc., San Diego, CA). One-way or 2-way analysis of variance (ANOVA) followed by Tukey's multiple comparison test paired with repeated measures were carried out for statistical analysis as appropriate. $\mathrm{P}$ values less than 0.05 were regarded as statistically significant. 
A

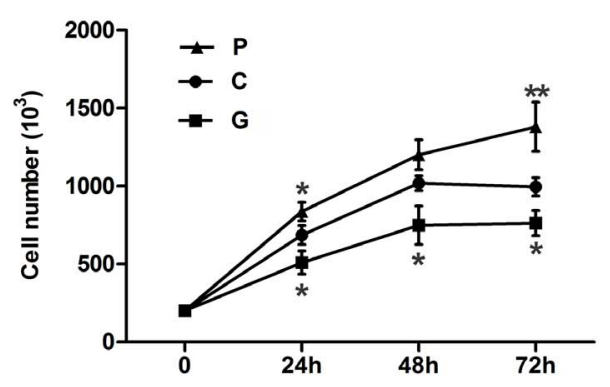

B
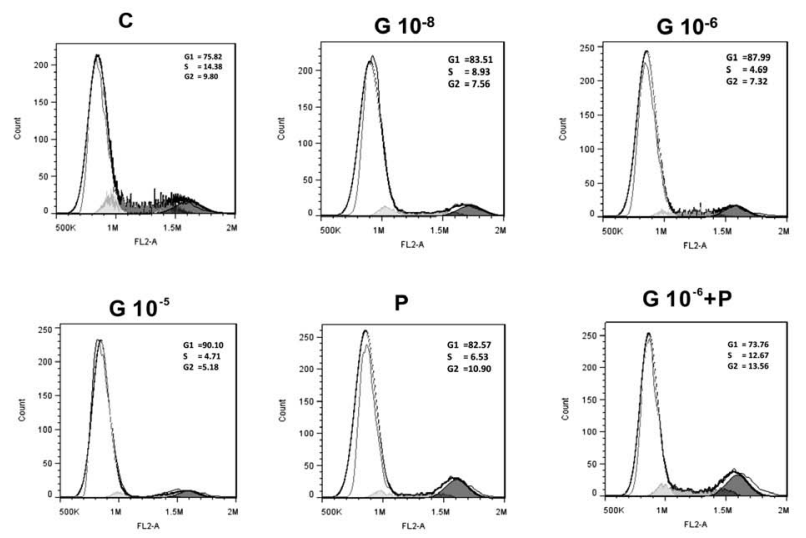

E
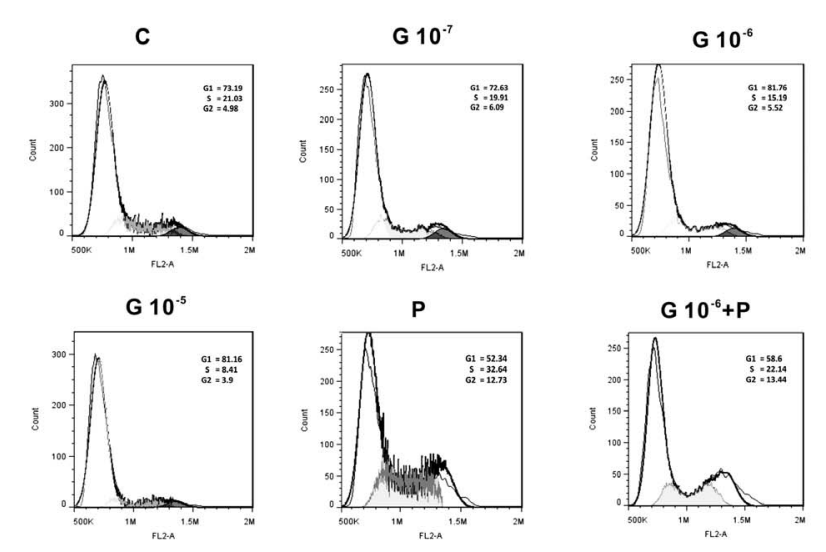

G
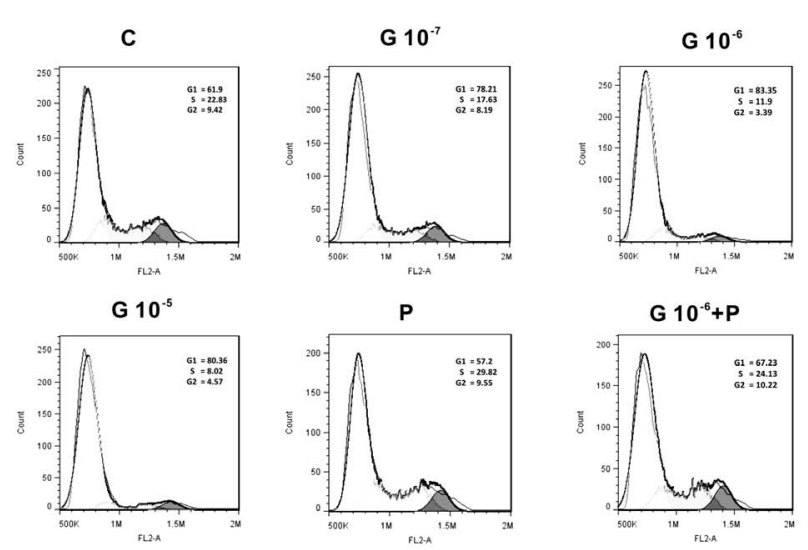

C

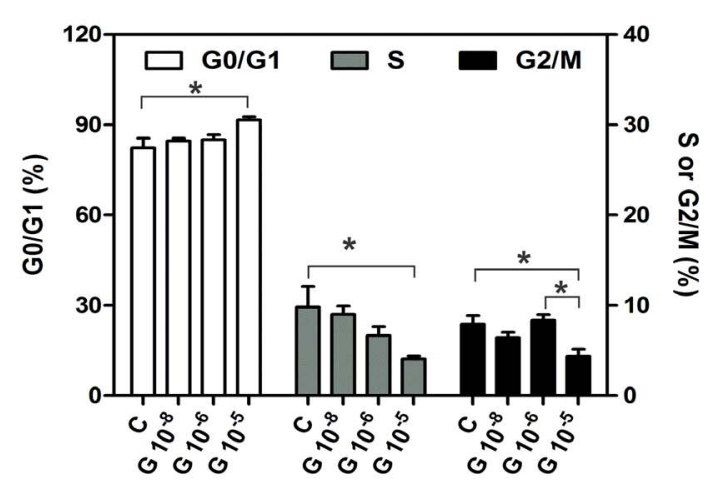

D

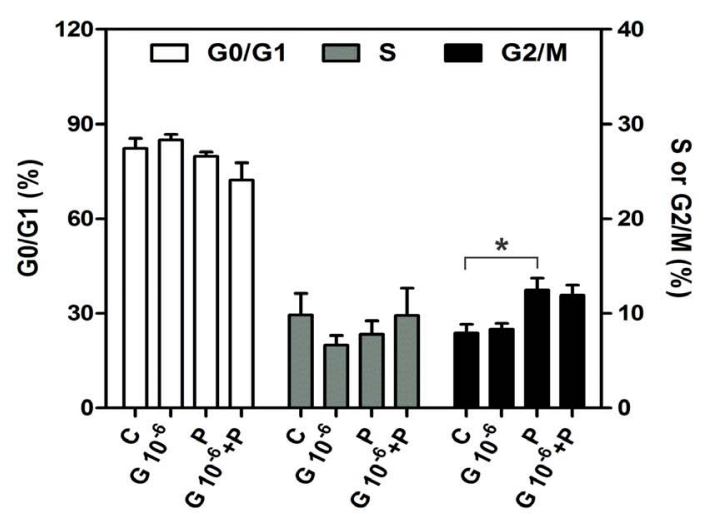

$\mathbf{F}$

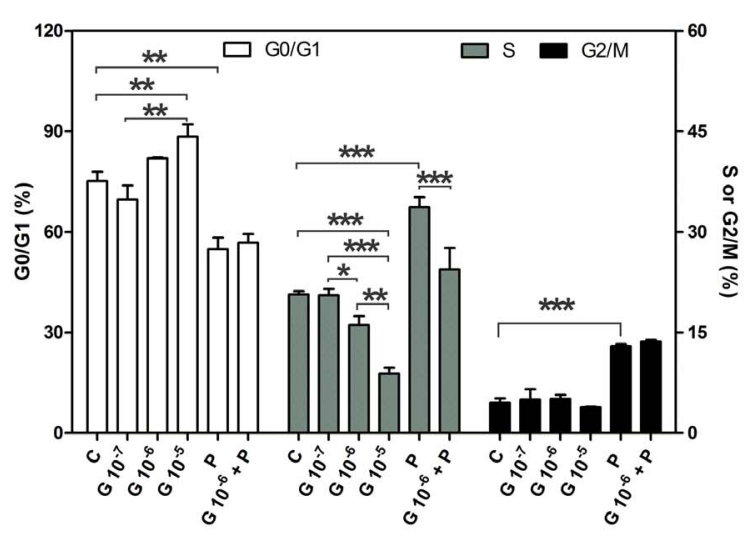

H

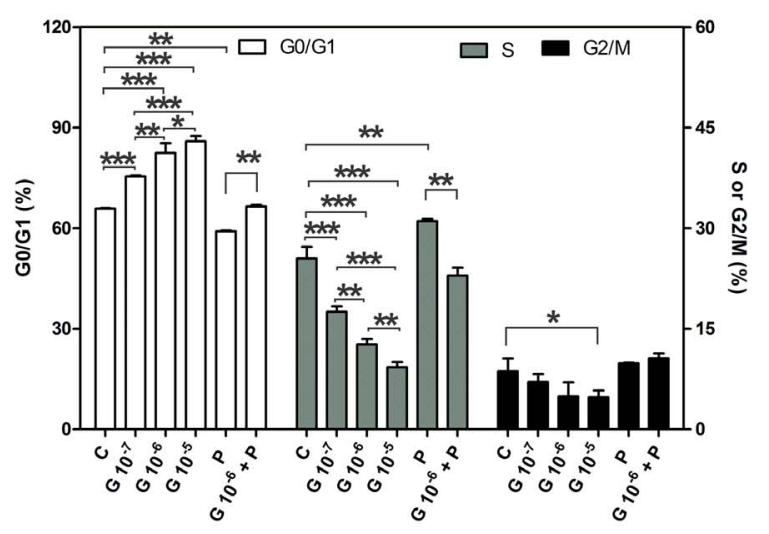


Figure 1. Reduced proliferation and delayed cell cycle progression of G-1 treated CASMCs cells. A: Cell proliferation curves of G-1 and/or PDGF-BB treated HCASMC cells. CASMCs were synchronized by 3 days of culturing in serum free and phenol red-free DMEM medium. Then $10 \%$ fetal calf serum (FCS) was added into medium and cells were counted manually with trypan-blue method (trypan-blue method of exclusion). B, E and G: $\operatorname{HCASMC}(B)$ and PCASMC $(E, G)$ cell cycle distribution was determined by propidium iodide staining of DNA content and flow cytometry. After synchronized, $10 \%$ FCS was added and cells were treated with vehicle as control (C); G-1 (G, $\left.10^{-8}-10^{-5} \mathrm{M}\right) ; 10 \mathrm{ng} / \mathrm{ml}$ PDGF-BB (P) or $1 \mu \mathrm{M} \mathrm{G}-1$ plus $10 \mathrm{ng} / \mathrm{ml}$ PDGF-BB (G+P) at 24 or 48 hours. Twenty-thousand cells per sample and three replicates per group were collected. Representative histograms are shown in C (G-1 concentration response); D, G+P, $1 \mu \mathrm{M} \mathrm{G}-1$ plus $10 \mathrm{ng} / \mathrm{ml} \mathrm{PDGF-BB}$, for $48 \mathrm{~h}$ treatment of HCASMC; F, 24 hour treatment and $\mathrm{H}, 48$ hour treatment of PCASMC with $1 \mu \mathrm{M} \mathrm{G}-1$ plus $10 \mathrm{ng} / \mathrm{ml}$ PDGF-BB. Representative histograms are shown as the mean \pm SD $(n=3)$, a significant difference is indicated by either ${ }^{*} p<0.05 ;{ }^{* *} p<0.01$ or ${ }^{* * *} p<0.001$, one-way or two-way ANOVA.

doi:10.1371/journal.pone.0064771.g001

\section{Results}

\section{GPER activation reduces CASMC proliferation}

We examined the action of GPER in controlling both primary human and porcine CASMC proliferation. Human CASMCs (passage 6-8) treated with G-1 displayed reduced cell growth (Figure 1A), for example, treating cells with $1 \mu \mathrm{M} \mathrm{G}-1$ for $24 \mathrm{~h}$ reduced cell growth by $26 \%$. In contrast, the pro-proliferative agent platelet-derived growth factor (PDGF-BB, $10 \mathrm{ng} / \mathrm{ml}, 24 \mathrm{~h}$ treatment) increased cell number by $22 \%$. These results indicate that activation of GPER by G-1 represses cell proliferation of human CASMCs.

The suppressive effect of G-1 on CASMCs was further investigated by analyzing cell cycle progression (Figure 1; table 1-3). Cells were cultured in 10\% FCS after synchronization. G-1 $\left(10^{-5} \mathrm{M}\right)$ significantly decreased the proportion of human CASMCs in phases $\mathrm{S}$ and $\mathrm{G} 2 / \mathrm{M}$ by $58.76 \%$ and $44.75 \%$ respectively after $48 \mathrm{~h}$ treatment $(\mathrm{G}-1$ vs control, $\mathrm{P}<0.05, \mathrm{n}=3$; Fig. 1B, 1C). The addition of $10 \mathrm{ng} / \mathrm{ml}$ PDGF-BB in $10 \%$ FCS medium clearly stimulated cell growth with a marked increase in the cell proportion of S phase and G2/M cells at $48 \mathrm{~h}$ (Figure 1B, 1D; table 1). Although data indicated a clear trend for $1 \mu \mathrm{M} \mathrm{G}-1$ $48 \mathrm{~h}$ treatment lowering the proportion of stimulated cells in G2/M phase, this effect did not reach statistical significance compared to controls (Figure 1B, 1D). The relative higher passage of the human CASMCs might have contributed to the lesser effectiveness of G-1 on the addition of PDGF-BB in 10\% FCS compared to $10 \%$ FCS alone stimulated cell growth.

Swine models of coronary dysfunction are similar to those of humans in response to injury or pathophysiological conditions [22]. Therefore, we also employed primary porcine CASMCs and tested for GPER activation at a low passage (p2) (Figure 1E-1H; table 2-3). Compared to human CASMCs, the anti-proliferative effect of G-1 on porcine CASMC was more robust. Treatment with G-1 $\left(10^{-7}, 10^{-6}\right.$, or $\left.10^{-5} \mathrm{M}\right)$ alone significantly decreased the proportion of S phase cells at $24 \mathrm{~h}$ and G2/M-phase cells at $48 \mathrm{~h}$, while increased accumulation of cells at G0/G1 phase.
Furthermore, G-1 significantly suppressed $10 \%$ FCS plus $10 \mathrm{ng} /$ $\mathrm{ml}$ PDGF-BB-induced cell proliferation, as evidenced by a marked decrease of cell population in S phase $(\mathrm{p}<0.01, \mathrm{n}=4)$. These data indicate that G-1 significantly inhibits the proliferation of porcine CASMCs by slowing down the progression of the cell growth cycle from G0/G1 to S and G2/M-phase. Together with the data from human CASMCs, these data suggest that G-1-activated GPER can inhibit proliferation by controlling cell cycle progression in CASMCs in a concentration- and time-dependent manner.

\section{GPER activation represses cell cycle progression by inducing expression of p21 in human and porcine CASMCs}

There is increasing evidence for a critical role of the cyclindependent kinase inhibitor (CDK-I) p21 in repressing VSMC growth [23,24]. Accordingly, we examined whether p21 and other cell cycle regulatory molecules (i.e., the G1-phase-specific cyclin D1, and the G2/M-phase-specific cyclin B1) are involved in antiproliferative effects of GPER. Human CASMCs growth was synchronized by 3-day serum deprivation, and then cells were treated with $1 \mu \mathrm{M} \mathrm{G}-1$ in 10\% FCS. Cells were collected at 6, 24, 48 , or 72 hours for immunoblot analysis (Figure 2A and 2B). Immunoblot studies revealed that $\mathrm{p} 21$ proteins were up-regulated in G-1-treated cells at all-time points compared to vehicle-treated cells (Figure 2B). Unexpectedly, G-1 treatment increased cyclin D1 level (Figure 2B), but almost completely prevented cyclin B1 accumulation (Figure 2B). These data indicate that GPER activation by G-1 treatment accumulates cell population in G1 phase, but hinders the cell cycle from entering G2/M phase.

We then tested these effects of G-1 on porcine CASMCs. The protein levels of cell cycle regulatory molecules were examined at 24 and 48 hours by immunoblot analysis (Figure 2C and 2D). As expected, PDGF-BB clearly up-regulated expression of both cyclins D1 and B1, while p21 expression was down-regulated compared to controls (Figure 2D), further confirming the cell cycle accelerating effect of PDGF-BB in CASMCs. G-1, on the other hand, not only increased p21 expression and nearly prevented

Table 1. The effect of G-1 treatment on human CASMCs for 48 hours.

\begin{tabular}{|c|c|c|c|c|c|c|}
\hline & \multicolumn{2}{|l|}{ G0/G1 } & \multicolumn{2}{|l|}{$\mathbf{S}$} & \multicolumn{2}{|l|}{ G2/M } \\
\hline & Mean $\pm S D$ & $\begin{array}{l}\text { Change after } \\
\text { treatment }(\%)\end{array}$ & Mean $\pm S D$ & $\begin{array}{l}\text { Change after } \\
\text { treatment }(\%)\end{array}$ & Mean $\pm S D$ & $\begin{array}{l}\text { Change after } \\
\text { treatment }(\%)\end{array}$ \\
\hline Control & $82.27 \pm 5.58$ & & $9.82 \pm 3.96$ & & $7.91 \pm 1.64$ & \\
\hline $\mathrm{G} 10^{-8}$ & $84.58 \pm 1.68$ & 2.81 & $9.00 \pm 1.58$ & -8.35 & $6.42 \pm 1.00$ & -18.84 \\
\hline $\mathrm{G} 10^{-6}$ & $85.03 \pm 2.81$ & 3.26 & $6.64 \pm 1.76$ & -32.38 & $8.33 \pm 1.10$ & 5.31 \\
\hline $\mathrm{G} 10^{-5}$ & $91.58 \pm 1.80$ & 10.95 & $4.05 \pm 0.58$ & -58.76 & $4.37 \pm 1.39$ & -44.75 \\
\hline PDGF & $79.77 \pm 2.46$ & -2.96 & $7.78 \pm 2.47$ & -20.77 & $12.45 \pm 2.2$ & 57.40 \\
\hline $\mathrm{G} 10^{-6}+\mathrm{P}$ & $72.27 \pm 9.41$ & -12.54 & $9.78 \pm 4.10$ & -0.41 & $11.90 \pm 1.87$ & 50.44 \\
\hline
\end{tabular}


Table 2. The effect of G-1 on porcine CASMCs after 24 hour treatment.

\begin{tabular}{|c|c|c|c|c|c|c|}
\hline \multirow[t]{2}{*}{$24 \mathrm{~h}$} & \multicolumn{2}{|l|}{ G0/G1 } & \multicolumn{2}{|l|}{$\mathbf{s}$} & \multicolumn{2}{|l|}{ G2/M } \\
\hline & Mean $\pm S D$ & $\begin{array}{l}\text { Change after } \\
\text { treatment (\%) }\end{array}$ & Mean $\pm S D$ & $\begin{array}{l}\text { Change after } \\
\text { treatment (\%) }\end{array}$ & Mean $\pm S D$ & $\begin{array}{l}\text { Change after } \\
\text { treatment (\%) }\end{array}$ \\
\hline C & $75.15 \pm 2.77$ & & $20.68 \pm 0.49$ & & $4.51 \pm 0.67$ & \\
\hline $\mathrm{G} 10^{-7}$ & $69.68 \pm 4.17$ & -7.28 & $20.56 \pm 0.92$ & -0.58 & $5.01 \pm 1.53$ & 11.09 \\
\hline $\mathrm{G} 10^{-6}$ & $81.93 \pm 0.24$ & 9.02 & $16.12 \pm 1.32$ & -22.05 & $5.09 \pm 0.61$ & 12.86 \\
\hline $\mathrm{G} 10^{-5}$ & $88.43 \pm 3.70$ & 17.67 & $8.88 \pm 0.85$ & -57.06 & $3.84 \pm 0.08$ & -14.86 \\
\hline P & $54.80 \pm 3.48$ & -27.08 & $33.69 \pm 1.48$ & 62.91 & $12.96 \pm 0.33$ & 187.36 \\
\hline $\mathrm{G} 10^{-6}+\mathrm{P}$ & $56.76 \pm 2.60$ & -24.47 & $24.40 \pm 3.20$ & 17.99 & $13.63 \pm 0.27$ & 202.22 \\
\hline
\end{tabular}

doi:10.1371/journal.pone.0064771.t002

cyclin B1 accumulation at both 24 and 48 hours (in the presence of $10 \%$ FCS), but also inhibited the effects of PDGF-BB on p21 and cyclin $\mathrm{Bl}$ in a similar concentration-dependent manner (Figure 2D). However, the effect of G-1 on PDGF-BB-induced cyclin D expression was not significant (Figure 2D). Taken together, our results demonstrate that G-1 blocks cell cycle progression in late $\mathrm{Gl}$ phase before cyclin D1 degradation occurs and before cyclin $\mathrm{B} 1$ accumulates.

\section{GPER activation decreases phosphorylation of AKT and ERK $1 / 2$}

To understand the pathways that mediate GPER activation regulated cell proliferation, we next examined the effects of G-1 on extracellular signal-regulated protein kinases (ERKs)-1 and 2 (ERK1/2) and Akt - two signaling systems that powerfully impact cell proliferation in breast and prostate cancer cells [25-27]. After serum deprivation, human CASMCs (passage 7-8) were treated with $10 \mathrm{ng} / \mathrm{ml}$ PDGF-BB for the indicated times (total period of 60 minutes) in the presence of $10 \%$ FCS. Control groups were treated with vehicle only. PDGF-BB-treated cells showed a significant increase of phosphorylated Akt and ERK1/2 over 60 min compared to controls (Figure 3A; $\mathrm{P}<0.05, \mathrm{n}=3$ ). In contrast, human CASMCs treated with $1 \mu \mathrm{M}$ G-1 exhibited decreased phosphorylation of both ERK1/2 and Akt at each time point, with the exception of p-Akt at 2-minutes, compared to vehicle-treated controls (Figure 3B).

Because our cell cycle results revealed a stronger G-1 effect in porcine CASMCs (passage 2) compared to human CASMCs (passage 7-8), we next tested the effect of G-1 on ERK1/2 and Akt phosphorylation induced by $10 \%$ FCS or $10 \% \mathrm{FSC}$ plus $10 \mathrm{ng} / \mathrm{ml}$ PDGF-BB in porcine CASMCs. G-1 $\left(10^{-7}-10^{-5} \mathrm{M}\right)$ inhibited FCS-induced phosphorylation of ERK $1 / 2$ and Akt in a concentration-dependent fashion. Moreover, G-1 inhibited the enhanced phosphorylation of Akt and ERK induced by the addition of $10 \mathrm{ng} / \mathrm{ml}$ PDGF-BB in 10\% FSC medium (Figure 3C). These results demonstrated that the inhibitory effects of GPER activation by G-1 in CASMCs are mediated by suppressing ERK1/2 and Akt activation.

\section{G-1 stimulation changes CASMC morphology by increasing the protein level of $\alpha$-Actin and SM22}

Several lines of evidence suggest that p21 up-regulation and cell cycle arrest are necessary for cell differentiation [28,29]. Therefore, we postulated that G-1 might contribute to SMC differentiation. To test this possibility, we used Smooth Muscle Differentiation Supplement (SMDS) to induce differentiation of normal human and porcine CASMCs [30]. After 3-day synchronization, 10\% FCS was added to the medium and cells were then treated with $10 \mathrm{nM}$ or $1 \mu \mathrm{M} \mathrm{G}-1$. Vehicle-treated SMCs exhibited a typical SMC morphology: flattened and spindle shaped with central oval nuclei and long cytoplasmic extensions. Confluent cells appear aligned in parallel so that the broad nuclear region of a cell lies adjacent to the thin cytoplasmic area of another forming a "hill-and-valley" appearance. Cells treated with SMDS displayed a change in cellular morphology from slender stellate cells to enlarged rectangular-shaped cells. Furthermore, immunocytochemistry demonstrated increased amounts of smooth muscle $\alpha$-actin. A more contractile phenotype and increased $\alpha$-actin was

Table 3. The effect of G-1 on porcine CASMCs after 48 hour treatment.

\begin{tabular}{|c|c|c|c|c|c|c|}
\hline \multirow[t]{2}{*}{$48 h$} & \multicolumn{2}{|l|}{ G0/G1 } & \multicolumn{2}{|l|}{$\mathbf{S}$} & \multicolumn{2}{|l|}{ G2/M } \\
\hline & Mean $\pm S D$ & $\begin{array}{l}\text { Change after } \\
\text { treatment (\%) }\end{array}$ & Mean $\pm S D$ & $\begin{array}{l}\text { Change after } \\
\text { treatment }(\%)\end{array}$ & Mean $\pm S D$ & $\begin{array}{l}\text { Change after } \\
\text { treatment (\%) }\end{array}$ \\
\hline C & $65.86 \pm 0.16$ & & $25.48 \pm 1.74$ & & $8.66 \pm 1.91$ & \\
\hline G $10^{-7}$ & $75.40 \pm 0.32$ & 14.49 & $17.53 \pm 0.82$ & -31.20 & $7.07 \pm 1.14$ & -18.36 \\
\hline G $10^{-6}$ & $82.42 \pm 2.94$ & 25.14 & $12.66 \pm 0.84$ & -50.31 & $4.92 \pm 2.09$ & -43.19 \\
\hline G $10^{-5}$ & $85.94 \pm 1.56$ & 30.49 & $9.27 \pm 0.75$ & -63.62 & $4.79 \pm 1.00$ & -44.69 \\
\hline$P$ & $59.10 \pm 0.19$ & -10.26 & $31.08 \pm 0.29$ & 21.98 & $9.82 \pm 0.10$ & 13.39 \\
\hline $\mathrm{G} 10^{-6}+\mathrm{P}$ & $66.48 \pm 0.42$ & 0.94 & $22.93 \pm 1.17$ & -10.01 & $10.59 \pm 0.74$ & 22.29 \\
\hline
\end{tabular}

The numbers in Tables $1-3$ are from Figure $1 \mathrm{~B}-\mathrm{H}$.

doi:10.1371/journal.pone.0064771.t003 
A

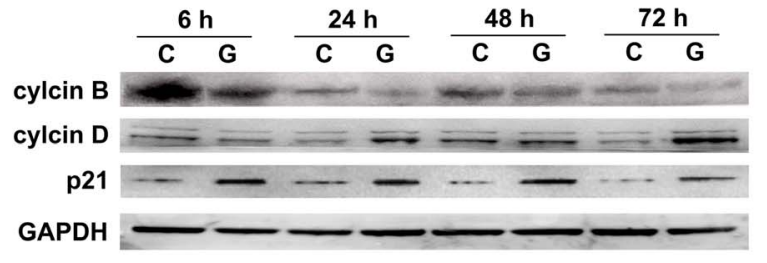

B

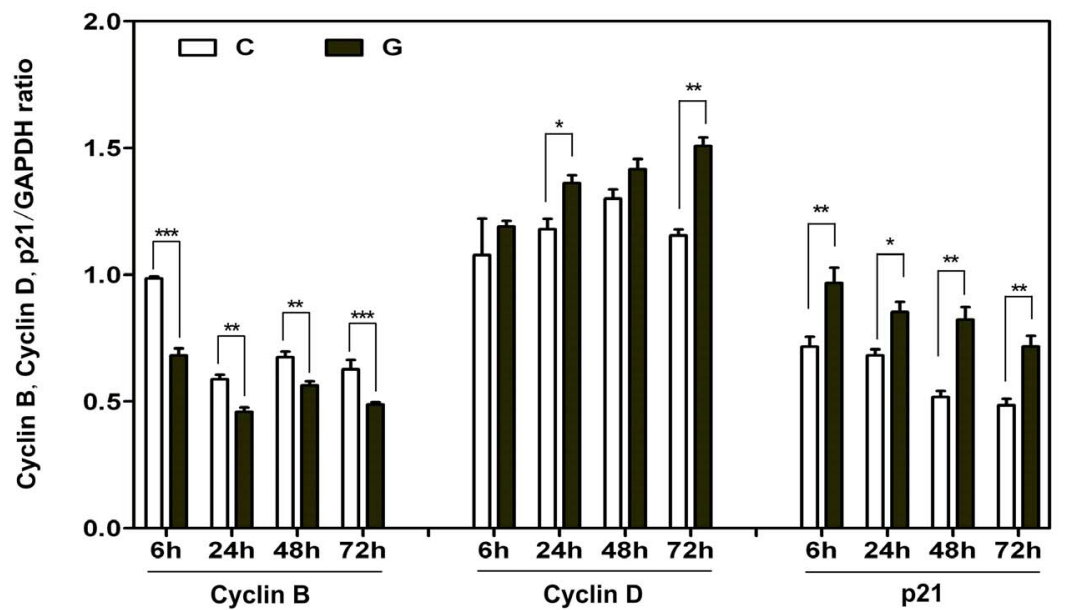

C

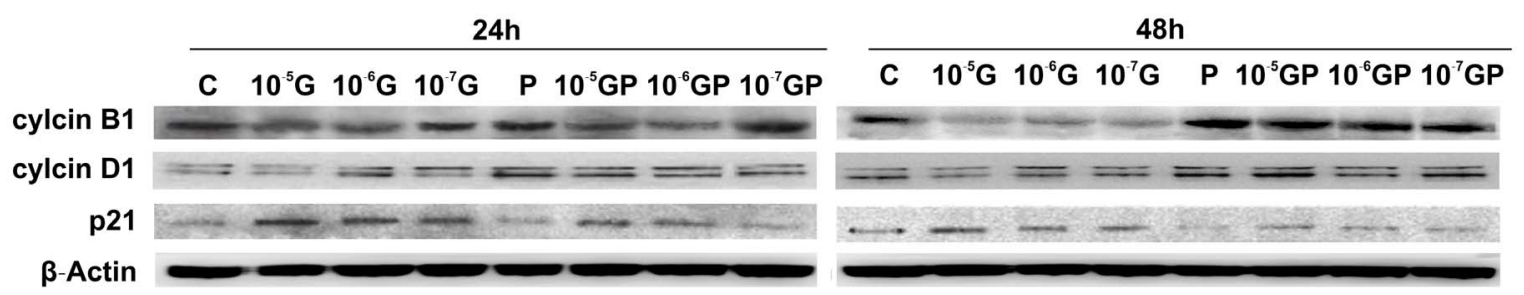

D

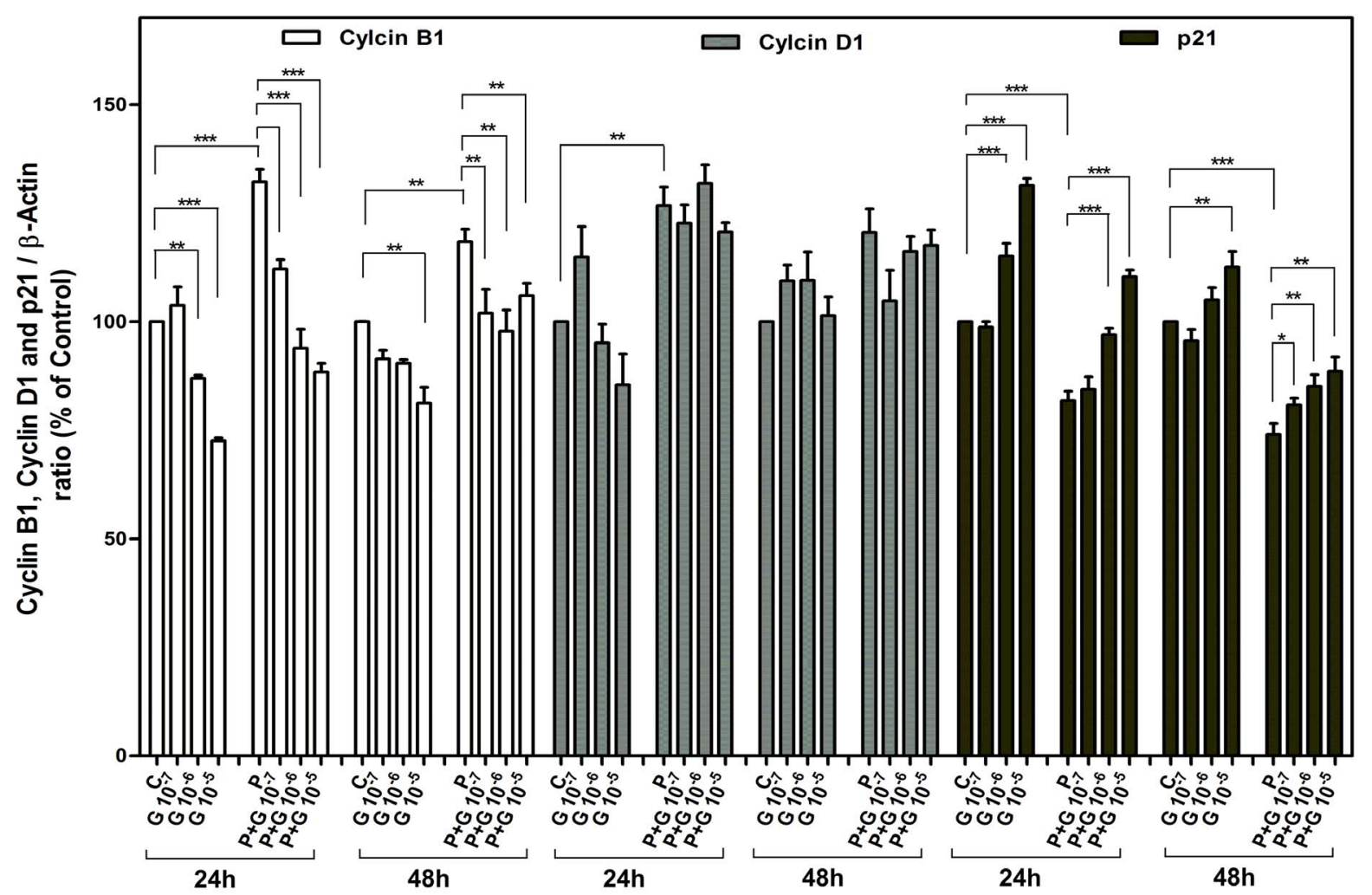


Figure 2. Effects of G-1 treatment on the protein level of cyclinB1, cyclinD1 and p21 in CASMCs. A and C: Western blot results of cyclinB1, cyclinD1 and p21 protein levels in human CASMCs (A) and porcine CASMCs (C). CASMCs were synchronized by 3 days of cultivation in

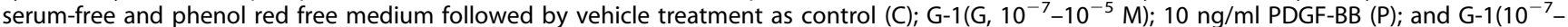
$\left.10^{-5} \mathrm{M}\right)$ plus $10 \mathrm{ng} / \mathrm{ml}$ PDGF treatment $(\mathrm{GP}$ or $\mathrm{P}+\mathrm{G})$ for 24 or 48 hours in the presence $10 \%$ FCS. Total cell extracts $\left(1 \times 10^{6}\right)$ were subjected to Western-blot analyses for cyclinB1, cyclinD1 and p21 level. B and D: Quantitative densitometric analyses of band intensities from 3 independent experiments. Data are normalized by GAPDH or $\beta$-Actin, expressed as the mean $\pm S D(n=3)$. A significant difference is indicated by either * $(p<0.05)$; $* *(p<0.01)$ or *** $(p<0.001)$ (one-way ANOVA). Representative histograms are shown.

doi:10.1371/journal.pone.0064771.g002

seen in both G-1-treated groups. Cells showed more enlarged rectangular or even triangular shaped cells in human CASMCs (Figure 4, left side two panels). These phenotypic characteristics were even more pronounced in porcine CASMCs (Figure 4, right side two panels). After prolonged G-1 exposure some cells exhibited an increased stacking of $\alpha$-actin fibers giving the appearance of a "bird's nest" shape, and the upper panels of G$1(10 \mathrm{nM}$ and $1 \mu \mathrm{M})$-treated human and porcine CASMCs were selected areas for this "bird's nest" shape morphology change. Further, G-1 produced a much greater increase of smooth muscle $\alpha$-actin and SM22 $\alpha$ than that of cells treated with SMDS alone (Figure 5). For example, $\alpha$-actin expression induced by $10 \mathrm{nM} \mathrm{G-1}$ (2-day treatment, human and porcine CASMCs) was $46.62 \%$ and $79.23 \%$ greater, respectively, compared to $\alpha$-actin expression in SMDS-treated cells $\mathrm{P}<0.01 \quad(\mathrm{n}=3)$. Collectively, these data demonstrate that GPER activation induces a differentiated VSMC phenotype.

\section{GPER activation inhibits PCNA expression in CASMCs}

Proliferating cell nuclear antigen (PCNA) expression increases as mitogens (such as PDGF) or serum stimulates VSMC proliferation [31]. In order to determine the effect and specificity of G-1 on proliferation we knocked-down expression of GPER via siRNA transfection studies, and then determined the effect of G-1 on PCNA expression and cell morphology in serum-stimulated human CASMCs. In control cells transfected with non-target siRNA, $10 \mathrm{nM}$ or $1 \mu \mathrm{M}$ G-1 clearly decreased serum-induced increases in PCNA expression, (Figure $6 \mathrm{~A}, \mathrm{~B}$ ) and also changed cell morphology into a more enlarged rectangular shape. In contrast, G-1 failed to exert an inhibitory effect on PGNA expression in cells transfected with GPER siRNA, and the effect on cell morphology was less compared to controls (Figure 6A). Western blotting confirmed the efficiency of GPER silencing with siRNA, as GPER expression deceased by 65-69.3\% (Figure 6C). Collectively, these results strongly suggest that G-1 inhibits CASMC proliferation via a GPER-mediated mechanism.

\section{GPER activation inhibits CASMC migration}

Vascular smooth muscle cell migration accompanies proliferation, and plays important role in the pathogenesis of atherosclerosis or arterial injury. Therefore, we tested the effect of G-1 on migration of porcine CASMCs. Cells were seeded on $35 \mathrm{~mm}$ dishes with Culture-Inserts, and grown in Medium 231 with SMGS. When cells reached $100 \%$ confluence, the inserts were removed leaving a $500 \mu \mathrm{M}$ gap in the growing cell population. Fresh growth medium was then added to the cells, which were exposed to different treatment conditions (Figure 7). After a $48 \mathrm{~h}$ incubation, cells from the control group migrated to the center of the dish, but did not fully cover the gap. $1 \mu \mathrm{M}$ G-1, however, completely inhibited cellular migration stimulated by the growth medium $(\mathrm{p}<0.05$; Figure $7 \mathrm{~B})$. Addition of $5 \mu \mathrm{M}$ G15 to the growth medium did not affect control cell migration; however, the inhibitory effect of G-1 on cellular migration was attenuated significantly by G15 $(\mathrm{p}<0.05)$. Collectively these results suggest that GPER activation inhibits CASMC migration.

\section{Discussion}

GPER is a G protein-coupled receptor functioning independently from $\mathrm{ER} \alpha$ and $\mathrm{ER} \beta$ to regulate cellular and physiological responsiveness to estrogen $[14,30]$. To our knowledge, this study is the first to demonstrate effects of a selective GPER agonist, G-1, on coronary artery SMC differentiation, proliferation and migration, and to propose key mediators of this response. Previous studies indicate that GPER activation promotes cancer cell proliferation and migration primarily by producing connective tissue growth factor in a human breast cancer cell line SKBr3 [32,33]. In addition, tamoxifen, an ER $\alpha$ antagonist but GPER agonist, induces abnormal endometrial thickening and cell proliferation $[34,35]$. Expression of both GPER and ER $\alpha$ along with active EGFR signaling, is required for E2-stimulated and G1-stimulated proliferation of ovarian cancer cells [36]. In contrast to these proliferative effects, activation of GPER by G-1 inhibits growth of androgen-dependent and -independent prostate cancer cells in vitro and PC-3 xenografts in vivo [27]. Thus, GPER functions in a tissue- or cell-specific manner. In blood vessels the VSM layer is enlarged in arteries from GPER gene knockout female mice, indicating that GPER helps maintain VSMCs in a dedifferentiated state [18]. In addition, G-1 reduces serumstimulated human umbilical VSMC proliferation [16]. These findings are consistent with our results of G-1 inhibition of CASMCs proliferation or migration. Involvement of GPER in these inhibitory responses to G-1 was substantiated by our experiments indicating that the effect of G-1 on proliferation was attenuated in cells expressing GPER siRNA, whereas G-1induced inhibition of migration was inhibited significantly by $\mathrm{G}$ 15, a selective GPER antagonist.

E2 inhibits serum-stimulated cell growth of human CASMCs by $57 \%$ and arrests PDGF-BB stimulated cell cycle at the G1 phase in human aortic VSMC [10]. In contrast, we found that G-1 failed to effectively repress cell cycle progression after 24 hours in human CASMCs (passage 7-8). However, G-1 (24 hours) effectively inhibited serum-induced growth of primary CASMC from pig coronary artery, but failed to inhibit serum plus PDGF-induced cell growth of these cells. These findings indicate that the antiproliferative effect of G-1 on VSM is distinct from that of E2, and suggest a stronger anti-proliferative effect compared to G-1. Nonetheless, Haas et al. [16] found that G-1 reduced proliferation of human umbilical vein SMCs by $60-80 \%$. Interestingly, these cells lose expression of $\mathrm{ER} \alpha$ and $\mathrm{ER} \beta$ in culture, yet retain full GPER expression. Therefore, it appears that activation of GPER, like nuclear ER, exerts an anti-proliferative effect on VSM; however, it appears that when all three estrogen receptors are coexpressed that the nuclear receptors play the more dominant role in slowing proliferation. At present, however, potential cross-talk between GPER and $\operatorname{ER} \alpha$ or $\operatorname{ER} \beta$ and signaling events downstream from GPER activation in VSMC is unknown. Potential effects of G-1 on downstream signaling events are also unknown.

Our flow cytometry results indicate that G-1 increases the number of cells in the G1-phase, and hinders cell cycle transition into the $\mathrm{S}$ phase and G2/M phase. Moreover, G2/M phase- 
A

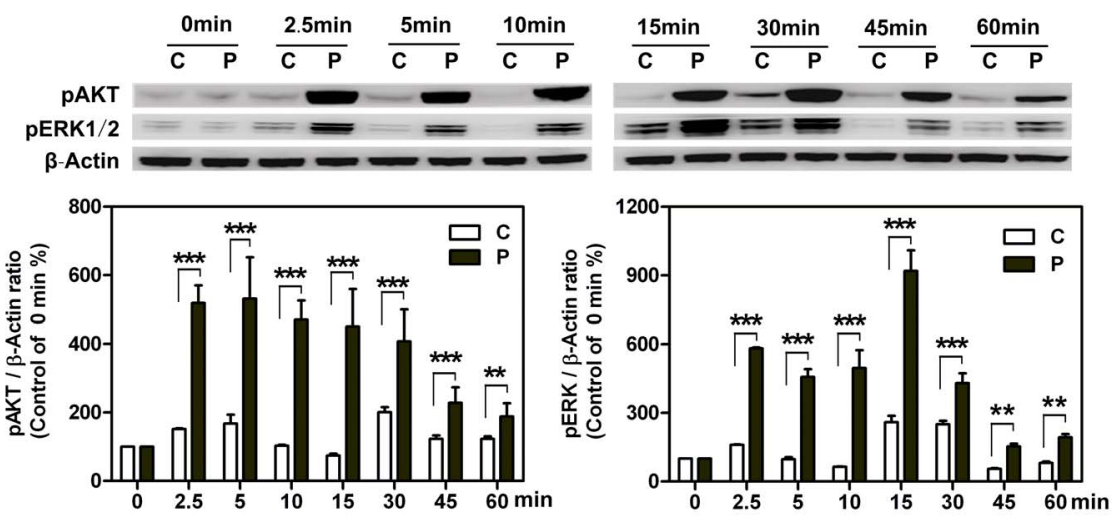

B
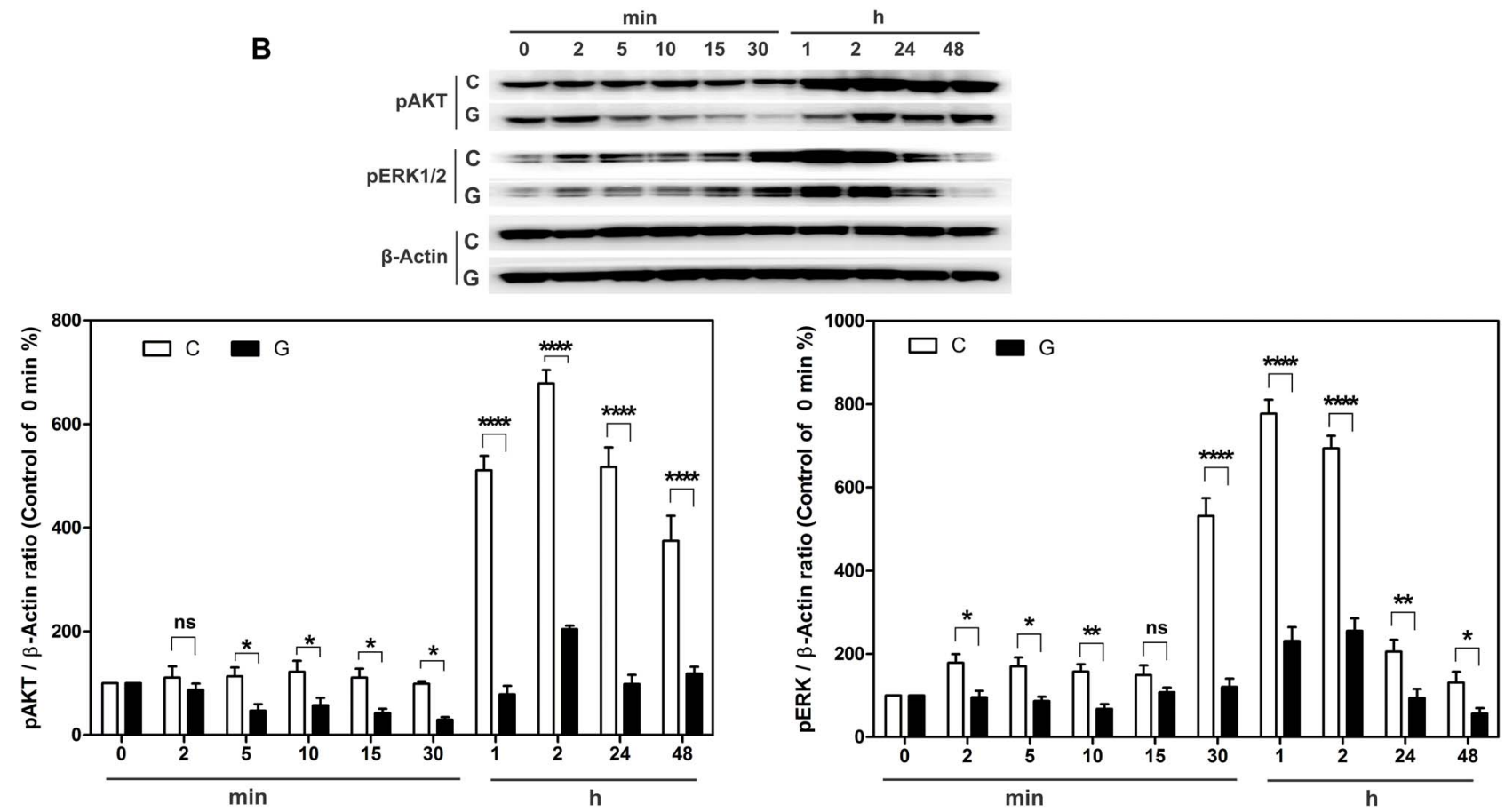

C
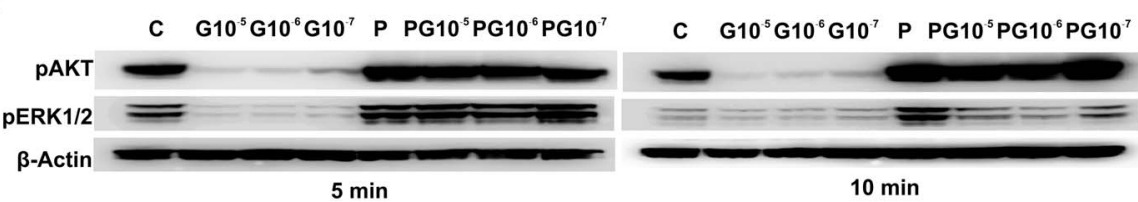

C $\quad \mathrm{G}_{10}{ }^{5} \mathrm{G} 10^{6} \mathrm{G} 10^{7} \mathrm{P}$ PG $10^{5} \mathrm{PG} 10^{6} \mathrm{PG}^{7} 0^{7}$
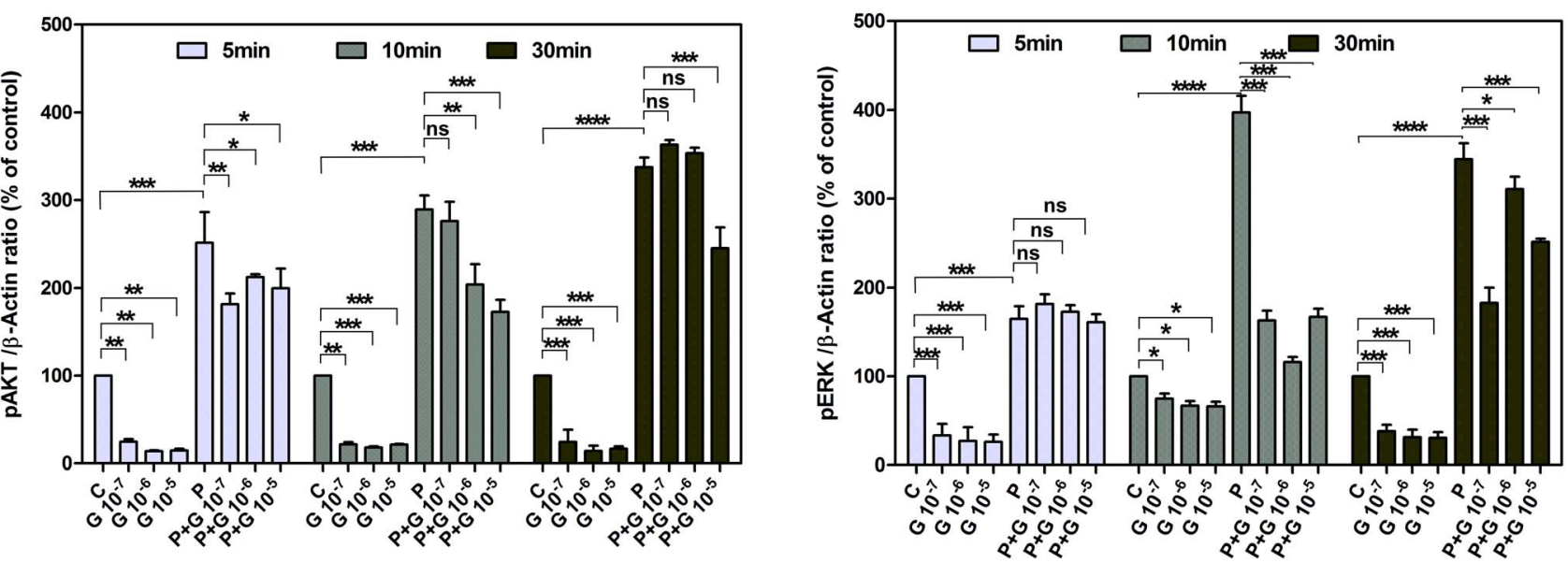
Figure 3. G-1 inhibits the phosphorylation of Akt and ERK1/2 in CASMCs. A and B: HCASMCs were cultured in serum and phenol red free medium for two days followed by PDGF-BB $(10 \mathrm{ng} / \mathrm{ml})(\mathrm{A})$ or G-1 $(1 \mu \mathrm{M})$ treatment $(B)$ for indicated time in the presence of $10 \%$ FCS. C: PCASMCs were cultured in the same medium for two days followed by G-1 $\left(10^{-7}-10^{-5} \mathrm{M}\right)$; PDGF-BB $(10 \mathrm{ng} / \mathrm{ml})$; and G- $1\left(10^{-7}-10^{-5} \mathrm{M}\right)$ plus PDGF-BB $(10 \mathrm{ng} / \mathrm{ml})$ treatments for indicated time in the presence of $10 \%$ FCS. Total cell extracts $\left(1 \times 10^{6}\right)$ were subjected to Western-blot analyses for Phospho-Akt and ERK1/2 level. Under the Western blot panels, a quantitative representation of the expression analysis from 3 independent experiments is shown. Vehicle-treated CASMCs cells were used as control. Data are normalized by $\beta$-Actin and expressed as means $\pm S D(n=3)$. A significant difference is indicated by either **** $p<0.0001$, *** $p<0.001$, ${ }^{* *} p<0.01$ or ${ }^{*} \mathrm{p}<0.05$ (one or two-way ANOVA); C, G and P represent control, G-1 and PDGF-BB treatment sample respectively, ns indicates no significant difference.

doi:10.1371/journal.pone.0064771.g003

A

B

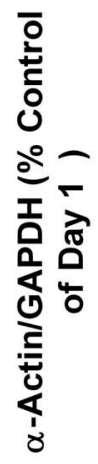

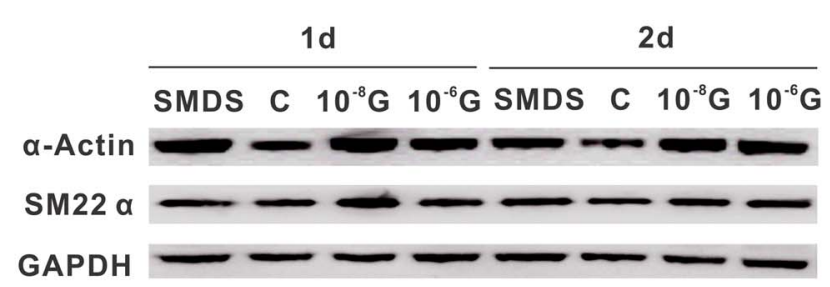

A

C

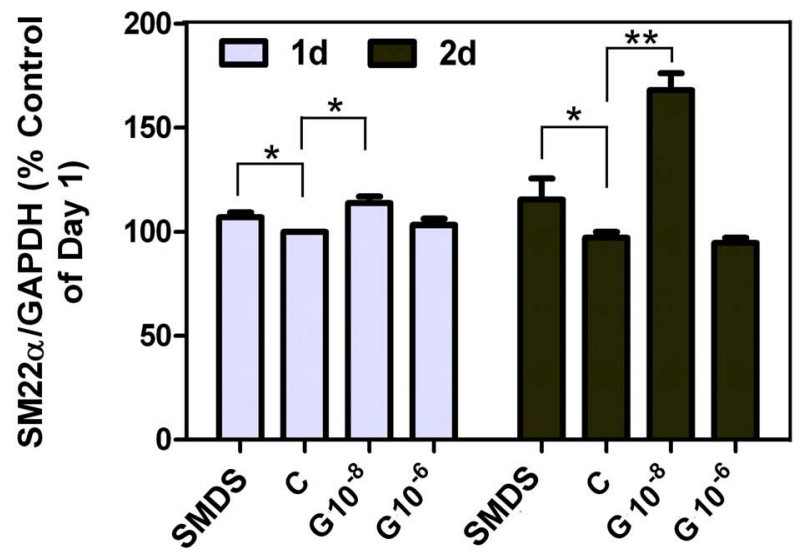

D

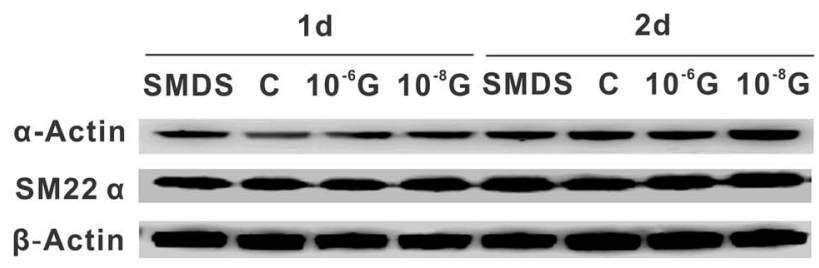

E

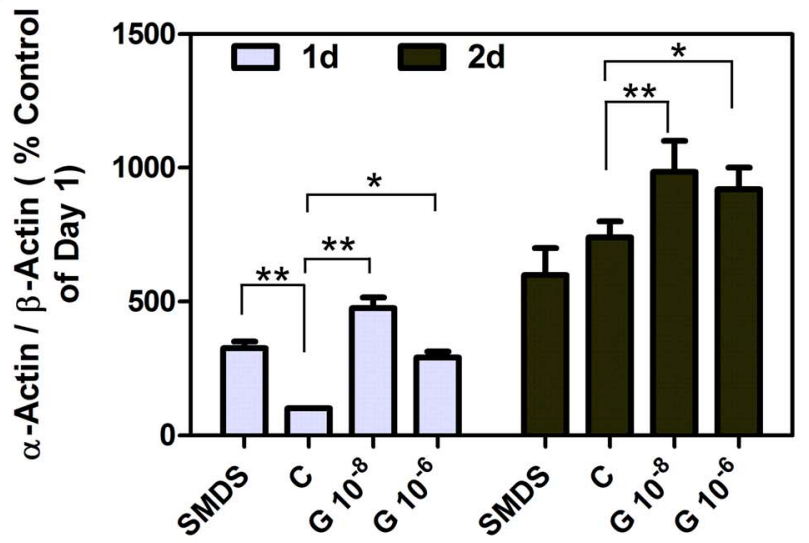

$\mathbf{F}$

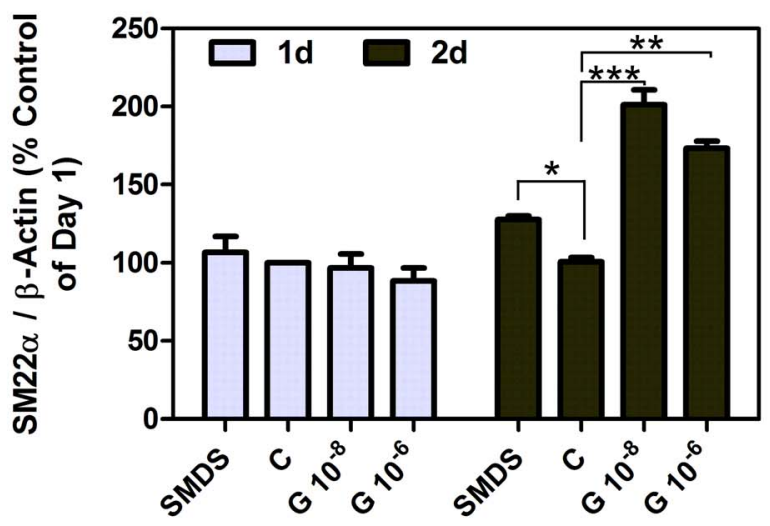

Figure 4. Effect of G-1 treatment on cell morphology in cultured CASMCs. Human and porcine CASMCS were incubated in the presence of either a SMDS or G-1 ( $1 \mu \mathrm{M}$ and $10 \mathrm{nM}$ ) for 1 and 2 day followed by immunostaining using anti- $\alpha$-smooth muscle antibody and FITC-conjugated antirabbit lgG secondary antibody (green).

doi:10.1371/journal.pone.0064771.g004 


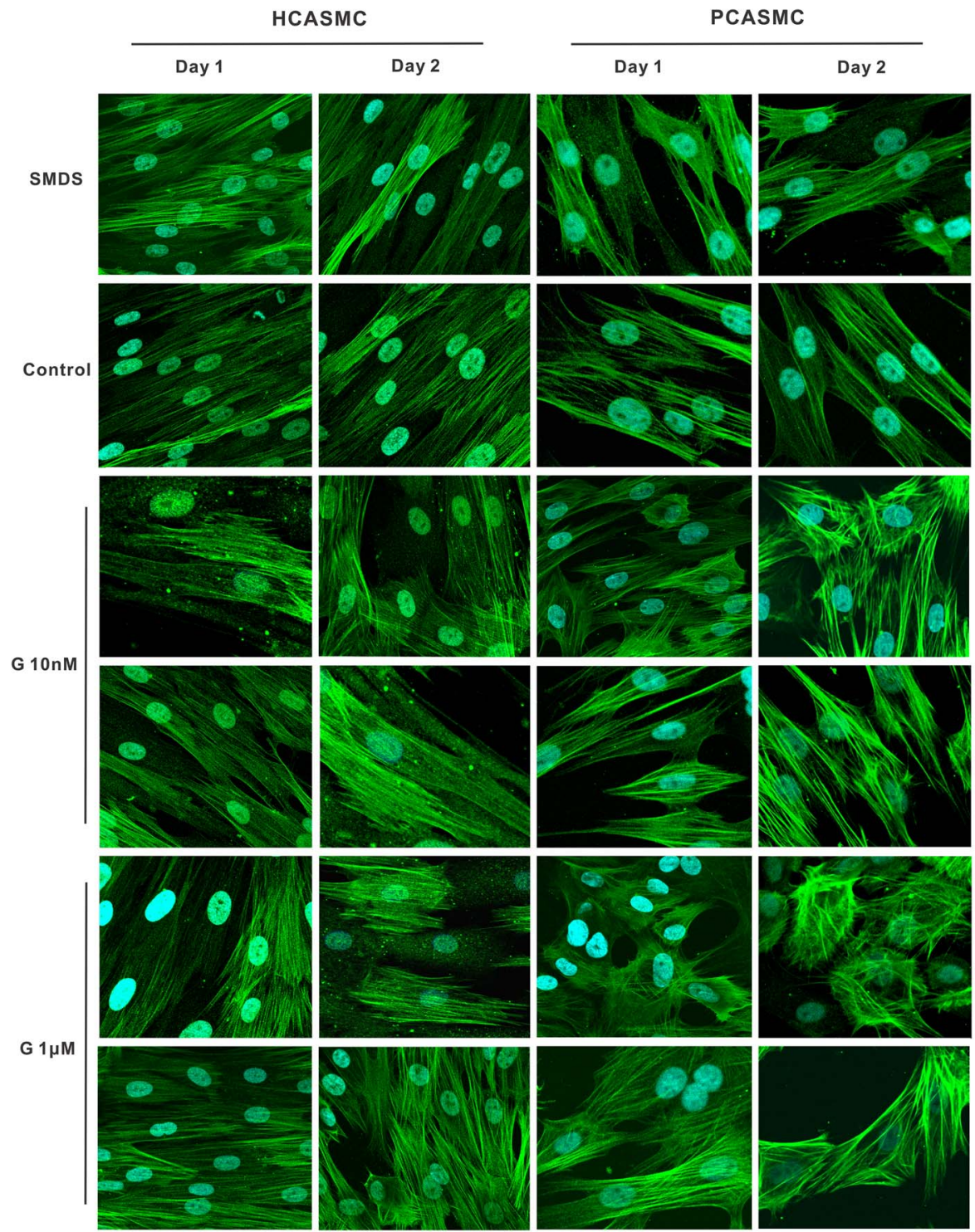

Figure 5. Effect of G-1 treatment on the protein level of $\alpha$-smooth muscle actin and SM22 $\alpha$ in CASMCs. A and D: changes of $\alpha$-smooth muscle actin and SM22 $\alpha$ protein in SMDS and G-1 treated human (A) and porcine (D) CASMC. Expression of $\alpha$-smooth muscle actin and SM22 $\alpha$ protein were determined by immunoblot analysis. SM22 $\alpha$ and $\alpha$-smooth muscle actin were increased in G- 1 treated cells in a concentration and timedependent manner. SM22 $\alpha$ and $\alpha$-smooth muscle actin expression was quantified by densitometric analysis from 3 independent experiments. Data are normalized by GAPDH (HCASMC) and $\beta$-Actin (PCASMC), expressed as the mean $\pm S D(n=3)$. ${ }^{*} P<0.05,{ }^{* *} P<0.01$ vs control (one-way ANOVA). Representative histograms are shown in $B, C$ and $E, F$. doi:10.1371/journal.pone.0064771.g005

specific cyclin B1 was strongly down-regulated by G-1. Cell-cycle progression from the G1-phase of the cell cycle to $\mathrm{S}$ phase entry is tightly regulated by cyclin-dependent kinases and their cyclinregulatory subunits. Because cyclin $\mathrm{B} 1$ is essential for $\mathrm{G} 2 / \mathrm{M}$ phase transition entry into mitosis, our finding of G-1-induced downregulation of cyclin $\mathrm{B} 1$ is consistent with an anti-proliferative effect of G-1 on CASMCs. In addition to cyclin B1, cyclin D1 gene is frequently overexpressed in VSMC under growth factor stimulation, and its down-regulation has been proposed to be associated with G1-phase arrest of cell growth [37,38]. Unexpectedly, we found that expression of G1-S phase specific cyclin D1 was upregulated by G-1 in VSMCs. Obviously, cyclin D1 was not involved in G-1-induced inhibition of cell cycle progression from G1-into S-phase. This finding seems to differ from a previous report where $17 \beta$-estradiol suppressed PDGF-stimulated progression from G1- to
S-phase in human aortic artery smooth muscle proliferation, possibly by inhibiting PDGF-induced phosphorylation of retinoblastoma protein $(\mathrm{pRb})$ or by reducing cyclin D1 expression [10]. Therefore, GPER may function differently from $\mathrm{ER} \alpha$ and $\mathrm{ER} \beta$ : GPER does not mediate inhibition of cyclin D1 expression nor $\mathrm{pRb}$ phosphorylation in VSMC. Although G-1-induced up-regulation of cyclin Dl is unexpected, it is not surprising as studies have shown that cell differentiation can be promoted by up-regulation of cyclin D1 and p21 [28].

The re-differentiation process of synthetic VSMC is coupled to withdrawal from the proliferation cell cycle, and we examined how G-1 affects smooth muscle cell differentiation marker protein expression in both porcine and human CASMCs. Differentiation induced by SMDS [39,40] changed cellular morphology from slender stellate cells to enlarged rectangular shaped cells, and 
A
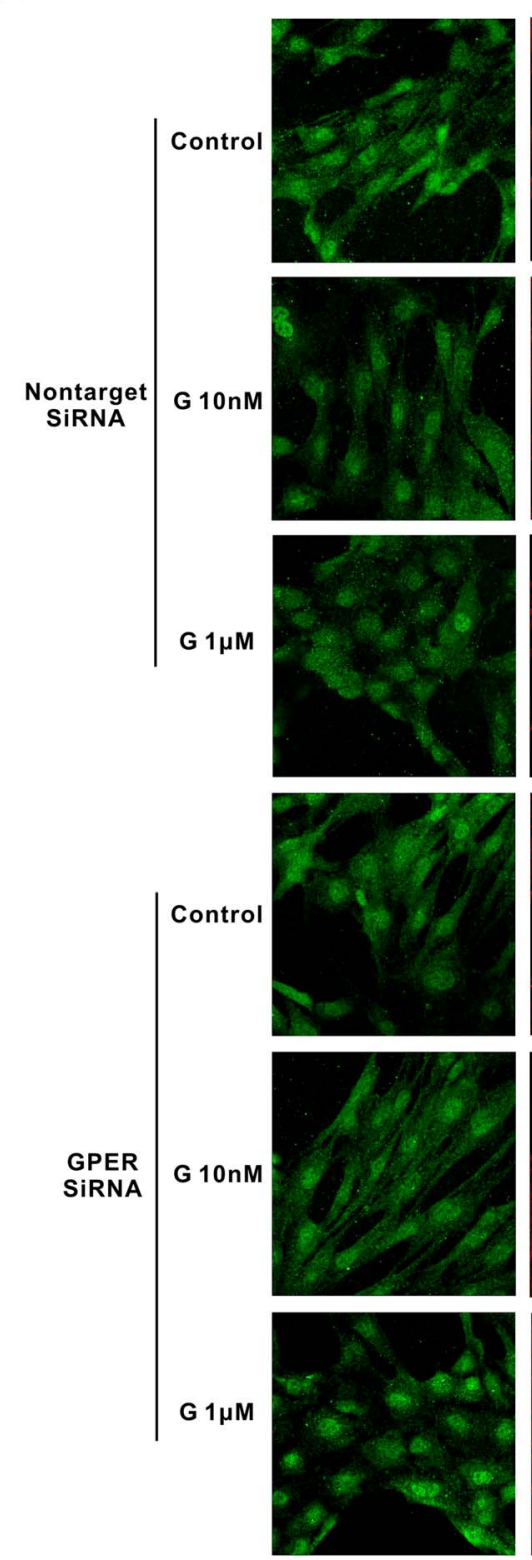

B

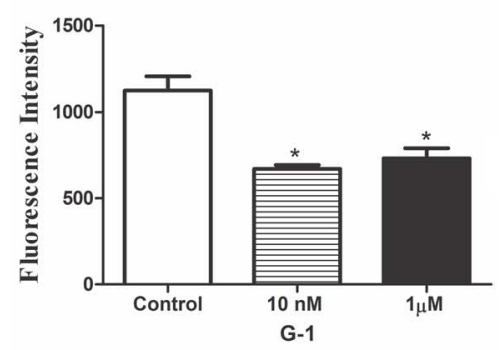

F-Actin
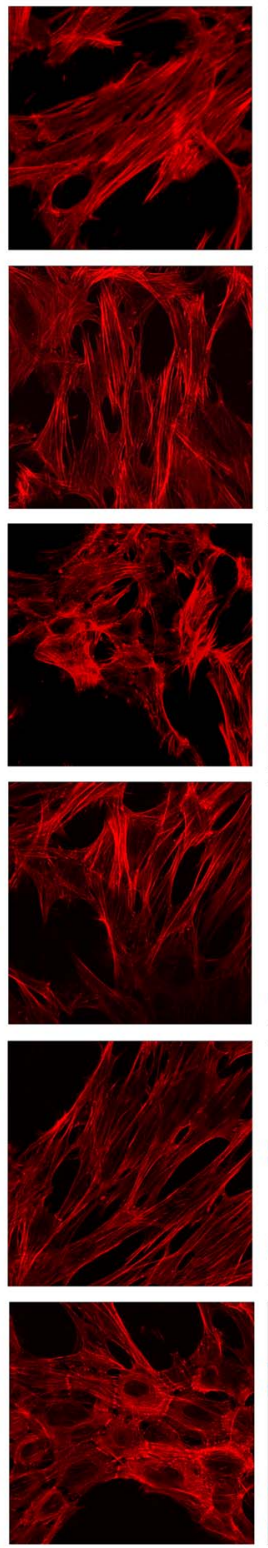

C
DAPI
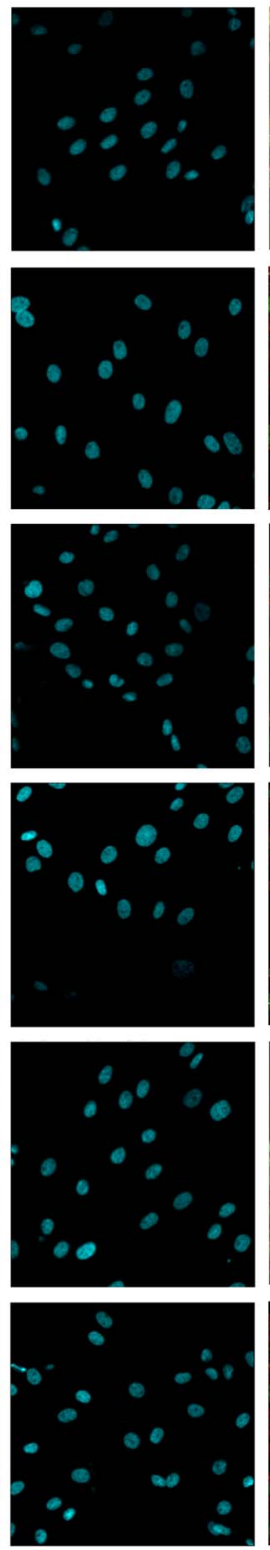

Merge
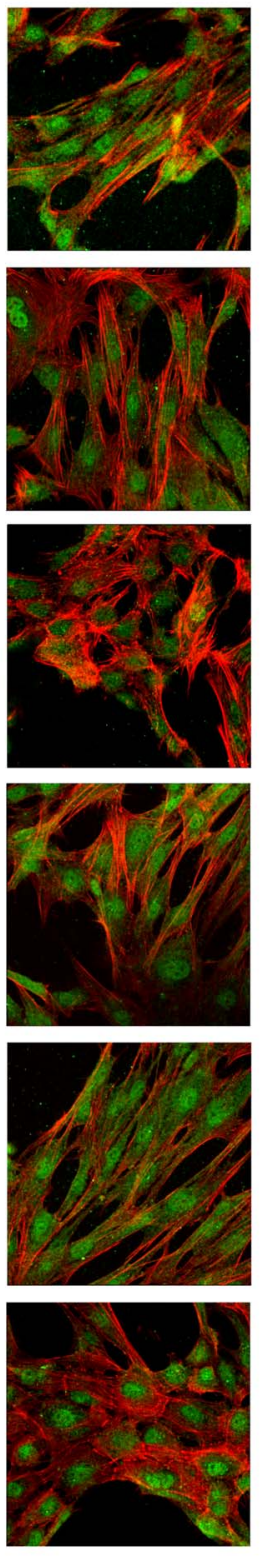

$\beta$-Actin

GPER

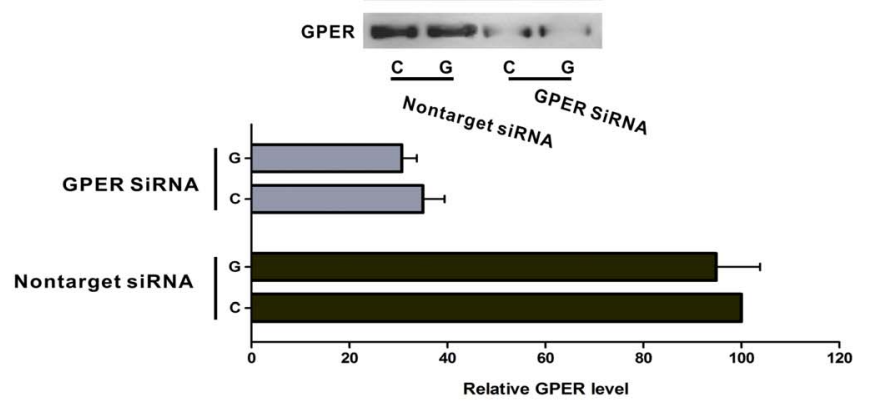

Figure 6. Down-regulation of GPER reverses the decreased expression of PCNA and cell morphology changes caused by G-1. (A) HCASMC cells transfected with non-targeted siRNA or GPER siRNA were incubated with G-1 (1 $\mu \mathrm{M}$ or $10 \mathrm{nM})$ for 48 h, followed by immunostaining using anti-PCNA antibody and FITC-conjugated anti-rabbit IgG secondary antibody (green). Cells were then stained by acti-stainTM555 Fluorescent phalloidin for F-actin to reveal cell morphology. Slides were mounted with ProLong Gold anti-fade regent with DAPI (Invitrogen Life Technologies, Gaithersburg, MD, USA) for imaging. (B) The expression of PCNA were presented as mean fluorescence intensities \pm S.E. of at least 50 cells collected from at least 5 random areas per sample and were analyzed statistically by ANOVA followed by Tukey's multiple comparison test. *Indicates significant difference from control at $p<0.05$. (C) GPER protein levels were measured by immunoblotting in siRNA-transfected cells $48 \mathrm{~h}$ following transfection.

doi:10.1371/journal.pone.0064771.g006 
A

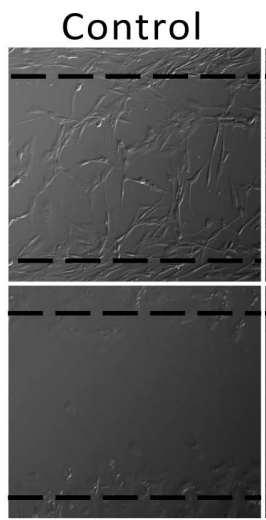

G-1
G15

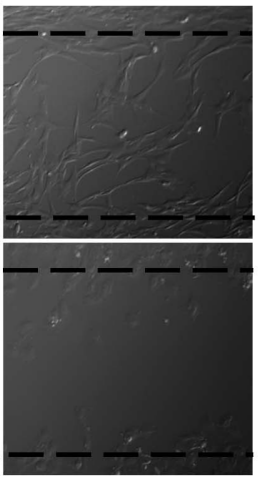

$\mathrm{G} 15+\mathrm{G}-1$

B

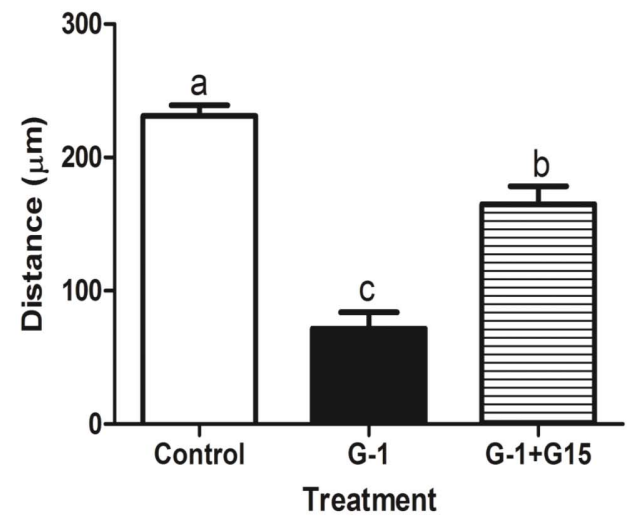

Figure 7. Effect of GPER stimulation on CASMC migration. (A) Representative of three experiments of porcine CASMC migration study. Cellular migration was assessed by using scratch-wound assay. Cells were cultured in ibidi $\mu$-dish culture insert until they reached confluence. Inserts ( $500 \mu \mathrm{m}$; dashed lines) were then removed, and cells were exposed to control media or media supplemented with either $1 \mu \mathrm{M} \mathrm{G}-1$ or $1 \mu \mathrm{M} \mathrm{G}-1+5 \mu \mathrm{M}$ G15. Five images per treatment were collected immediately and then $48 \mathrm{~h}$ following insert removal. Within a specific image five different distances were measured from the edge of the dashed-line. (B) Each bar represents the mean distance traveled from the edge +/- SEM. Comparison between the different treatments was done with One-way ANOVA followed by Tukey's multiple comparison test, and treatment groups identified by different letter $(a, b$, or $c)$ indicate significant difference $(p<0.05)$ between each of the three experimental groups.

doi:10.1371/journal.pone.0064771.g007

VSMC $\alpha$-actin content was clearly increased, as predicted. However, G-1 exerted an even stronger effect than SMDS on cell morphology and $\alpha$-actin expression in both human and porcine CASMCs. Collectively, these data certainly demonstrate that GPER activation induces VSMC differentiation phenotype and repression of cell cycle progression. The mechanism of how this repression is coupled to re-differentiation is beyond the scope of the present study, but evidence suggests that increased p21 and cyclin D1 expression is correlated with differentiation of various cell types $[29,41,42]$. We found increased expression of p21 and cyclin D1 as early as 6 hours after exposure to G-1, and this effect persisted up to 72 hours - an effect which correlated with increased expression of VSMC $\alpha$-actin and SM22 $\alpha$ at the first and second day of CASMCs exposure to G-1. Taken together, these findings suggest that G-1-induced CASMC differentiation is related to greater expression of p21 and cyclin D1.

GPER has been shown to modulate ERK1/2 and Akt activity, which is dependent upon trans-activation of the epidermal growth factor (EGF) receptor via release of heparin-bound EGF (HB-EGF) in breast cancer cells [25]. We found that although phosphorylation levels of ERK1/2 and Akt in human and porcine CASMCs fluctuated somewhat over time, the overall effect of G-1 was to decrease phosphorylation. Pretreating CASMCs with G-1 led to a significant concentration-dependent decrease in serum-stimulated

\section{References}

1. Rzucidlo EM, Martin KA, Powell RJ (2007) Regulation of vascular smooth muscle cell differentiation. J Vasc Surg 45 Suppl A: A25-32.

2. Owens GK, Kumar MS, Wamhoff BR (2004) Molecular regulation of vascular smooth muscle cell differentiation in development and disease. Physiol Rev 84: 767-801.

3. Farhat MY, Lavigne MC, Ramwell PW (1996) The vascular protective effects of estrogen. Faseb J 10: 615-624.

4. Kawagoe J, Ohmichi M, Tsutsumi S, Ohta T, Takahashi K, et al. (2007) Mechanism of the divergent effects of estrogen on the cell proliferation of human umbilical endothelial versus aortic smooth muscle cells. Endocrinology 148: 6092-6099.

5. Dubey RK, Jackson EK, Gillespie DG, Zacharia LC, Imthurn B, et al. (2000) Clinically used estrogens differentially inhibit human aortic smooth muscle cell growth and mitogen-activated protein kinase activity. Arterioscler Thromb Vasc Biol 20: 964-972.
ERK1/2 and Akt phosphorylation. Apparently, GPER exerts a negative effect on ERK and Akt signaling in the presence of mitogens in CASMCs. This finding is consistent with studies by Filardo et al. [26] where GPER activation stimulated adenylyl cyclase activity in breast cancer cells and suppressed EGF-induced ERK1/2 activity. Whether cAMP signaling is involved in the G-1 effect on ERK1/2 activity in the CASMCs is an ongoing investigation in our laboratory. The present study provides new evidence that GPER plays an important role in regulating coronary artery smooth muscle growth, and promotes re-differentiation and a contractile phenotype in these cells. Furthermore, we propose GPER as a novel therapeutic target to prevent coronary artery dysfunction.

\section{Acknowledgments}

Confocal microscopy was performed in the Texas A\&M University College of Veterinary Medicine \& Biomedical Sciences Image Analysis Laboratory.

\section{Author Contributions}

Conceived and designed the experiments: FL GH. Performed the experiments: FL XY CS GM BZ RB. Analyzed the data: FL RB. Contributed reagents/materials/analysis tools: CLH JNS. Wrote the paper: FL REW GH.
6. Sivritas D, Becher MU, Ebrahimian T, Arfa O, Rapp S, et al. (2011) Antiproliferative effect of estrogen in vascular smooth muscle cells is mediated by Kruppel-like factor-4 and manganese superoxide dismutase. Basic Res Cardiol 106: 563-575.

7. Liu HM, Zhao XF, Guo LN, Tan Z, Wang TH (2007) Effects of caveolin-1 on the 17 beta-estradiol-mediated inhibition of VSMC proliferation induced by vascular injury. Life Sci 80: 800-812.

8. Selzman CH, Gaynor JS, Turner AS, Whitehill TA, Horwitz LD, et al. (1998) Estrogen replacement inhibits intimal hyperplasia and the accumulation and effects of transforming growth factor betal. J Surg Res 80: 380-385.

9. Foegh ML, Asotra S, Howell MH, Ramwell PW (1994) Estradiol inhibition of arterial neointimal hyperplasia after balloon injury. J Vasc Surg 19: 722-726.

10. Takahashi K, Ohmichi M, Yoshida M, Hisamoto K, Mabuchi S, et al. (2003) Both estrogen and raloxifene cause G1 arrest of vascular smooth muscle cells. J Endocrinol 178: 319-329. 
11. Iafrati MD, Karas RH, Aronovitz M, Kim S, Sullivan TR Jr, et al. (1997) Estrogen inhibits the vascular injury response in estrogen receptor alphadeficient mice. Nat Med 3: 545-548.

12. Karas RH, Hodgin JB, Kwoun M, Krege JH, Aronovitz M, et al. (1999) Estrogen inhibits the vascular injury response in estrogen receptor beta-deficient female mice. Proc Natl Acad Sci U S A 96: 15133-15136.

13. Karas RH, Schulten H, Pare G, Aronovitz MJ, Ohlsson C, et al. (2001) Effects of estrogen on the vascular injury response in estrogen receptor alpha, beta (double) knockout mice. Circ Res 89: 534-539.

14. Revankar CM, Cimino DF, Sklar LA, Arterburn JB, Prossnitz ER (2005) A transmembrane intracellular estrogen receptor mediates rapid cell signaling. Science 307: 1625-1630.

15. Thomas P, Pang Y, Filardo EJ, DongJ (2005) Identity of an estrogen membrane receptor coupled to a $\mathrm{G}$ protein in human breast cancer cells. Endocrinology 146: $624-632$.

16. Haas E, Bhattacharya I, Brailoiu E, Damjanovic M, Brailoiu GC, et al. (2009) Regulatory role of $\mathrm{G}$ protein-coupled estrogen receptor for vascular function and obesity. Circ Res 104: 288-291.

17. Lindsey SH, Cohen JA, Brosnihan KB, Gallagher PE, Chappell MC (2009) Chronic treatment with the $\mathrm{G}$ protein-coupled receptor 30 agonist G-1 decreases blood pressure in ovariectomized mRen2.Lewis rats. Endocrinology 150: 37533758 .

18. Martensson UE, Salehi SA, Windahl S, Gomez MF, Sward K, et al. (2009) Deletion of the $\mathrm{G}$ protein-coupled receptor 30 impairs glucose tolerance, reduces bone growth, increases blood pressure, and eliminates estradiol-stimulated insulin release in female mice. Endocrinology 150: 687-698.

19. Deschamps AM, Murphy E (2009) Activation of a novel estrogen receptor, GPER, is cardioprotective in male and female rats. Am J Physiol Heart Circ Physiol 297: H1806-1813.

20. Yu X, Ma H, Barman SA, Liu AT, Sellers M, et al. (2011) Activation of G protein-coupled estrogen receptor induces endothelium-independent relaxation of coronary artery smooth muscle. Am J Physiol Endocrinol Metab 301: E882888 .

21. Odenlund M, Holmqvist B, Baldetorp B, Hellstrand P, Nilsson BO (2009) Polyamine synthesis inhibition induces $\mathrm{S}$ phase cell cycle arrest in vascular smooth muscle cells. Amino Acids 36: 273-282.

22. Gupta GK, Dhar K, Del Core MG, Hunter WJ 3rd, Hatzoudis GI, et al. (2011) Suppressor of cytokine signaling-3 and intimal hyperplasia in porcine coronary arteries following coronary intervention. Exp Mol Pathol 91: 346-352.

23. Kim JS, Cross JM, Bamman MM (2005) Impact of resistance loading on myostatin expression and cell cycle regulation in young and older men and women. Am J Physiol Endocrinol Metab 288: E1110-1119.

24. Granada JF, Ensenat D, Keswani AN, Kaluza GL, Raizner AE, et al. (2005) Single perivascular delivery of mitomycin $\mathrm{C}$ stimulates p21 expression and inhibits neointima formation in rat arteries. Arterioscler Thromb Vasc Biol 25: 2343-2348.

25. Filardo EJ, Quinn JA, Bland KI, Frackelton AR Jr (2000) Estrogen-induced activation of Erk-1 and Erk-2 requires the G protein-coupled receptor homolog, GPR30, and occurs via trans-activation of the epidermal growth factor receptor through release of HB-EGF. Mol Endocrinol 14: 1649-1660.

26. Filardo EJ, Quinn JA, Frackelton AR Jr, Bland KI (2002) Estrogen action via the $\mathrm{G}$ protein-coupled receptor, GPR30: stimulation of adenylyl cyclase and cAMPmediated attenuation of the epidermal growth factor receptor-to-MAPK signaling axis. Mol Endocrinol 16: 70-84.
27. Chan QK, Lam HM, Ng CF, Lee AY, Chan ES, et al. (2010) Activation of GPR30 inhibits the growth of prostate cancer cells through sustained activation of Erk1/2, c-jun/c-fos-dependent upregulation of p21, and induction of $\mathrm{G}(2)$ cell-cycle arrest. Cell Death Differ 17: 1511-1523.

28. Ranganna K, Yousefipour Z, Yatsu FM, Milton SG, Hayes BE (2003) Gene expression profile of butyrate-inhibited vascular smooth muscle cell proliferation. Mol Cell Biochem 254: 21-36.

29. Tian JQ Quaroni A (1999) Involvement of p21(WAF1/Cipl) and p27(Kipl) in intestinal epithelial cell differentiation. Am J Physiol 276: C1245-1258.

30. Yu JJ, Kirkland TN, Hall LK, Wopschall J, Smith RC, et al. (2005) Characterization of a serodiagnostic complement fixation antigen of Coccidioides posadasii expressed in the nonpathogenic Fungus Uncinocarpus reesii. J Clin Microbiol 43: 5462-5469.

31. Zhao Y, Lv M, Lin H, Cui Y, Wei X, et al. (2013) Rho-associated protein kinase isoforms stimulate proliferation of vascular smooth muscle cells through ERK and induction of cyclin D1 and PCNA. Biochem Biophys Res Commun.

32. Yena S, Doddoli C, Doumbia S, D'Journo XB, Aragon A, et al. (2006) [Bronchial fistula postpneumonectomy: predictive factors]. Ann Chir 131: 2226.

33. Pandey DP, Lappano R, Albanito L, Madeo A, Maggiolini M, et al. (2009) Estrogenic GPR30 signalling induces proliferation and migration of breast cancer cells through CTGF. EMBO J 28: 523-532.

34. Ignatov T, Eggemann H, Semczuk A, Smith B, Bischoff J, et al. (2010) Role of GPR30 in endometrial pathology after tamoxifen for breast cancer. Am J Obstet Gynecol 203: 595 e599-516.

35. Filigheddu N, Sampietro S, Chianale F, Porporato PE, Gaggianesi M, et al. (2011) Diacylglycerol kinase alpha mediates 17-beta-estradiol-induced proliferation, motility, and anchorage-independent growth of Hec-1A endometrial cancer cell line through the G protein-coupled estrogen receptor GPR30. Cell Signal 23: 1988-1996.

36. Albanito L, Madeo A, Lappano R, Vivacqua A, Rago V, et al. (2007) G proteincoupled receptor 30 (GPR30) mediates gene expression changes and growth response to 17beta-estradiol and selective GPR30 ligand G-1 in ovarian cancer cells. Cancer Res 67: 1859-1866.

37. Yun ES, Park SS, Shin HC, Choi YH, Kim WJ, et al. (2011) p38 MAPK activation is required for esculetin-induced inhibition of vascular smooth muscle cells proliferation. Toxicol In Vitro 25: 1335-1342.

38. Mathew OP, Ranganna K, Yatsu FM (2010) Butyrate, an HDAC inhibitor, stimulates interplay between different posttranslational modifications of histone H3 and differently alters G1-specific cell cycle proteins in vascular smooth muscle cells. Biomed Pharmacother 64: 733-740.

39. Riendeau V, Garenc C (2009) Effect of 27-hydroxycholesterol on survival and death of human macrophages and vascular smooth muscle cells. Free Radic Res 43: 1019-1028.

40. Chaterji S, Park K, Panitch A (2010) Scaffold-free in vitro arterial mimetics: the importance of smooth muscle-endothelium contact. Tissue Eng Part A 16: 1901-1912.

41. Parker SB, Eichele G, Zhang P, Rawls A, Sands AT, et al. (1995) p53independent expression of p21Cip1 in muscle and other terminally differentiating cells. Science 267: 1024-1027.

42. Yan GZ, Ziff EB (1995) NGF regulates the PC12 cell cycle machinery through specific inhibition of the Cdk kinases and induction of cyclin D1. J Neurosci 15: $6200-6212$. 